3/ Linguaculture

\title{
TURNING ROMANTICISM ON ITS HEAD: THE PERIPHERAL SYMBOLIC GEOGRAPHY OF ALDOUS HUXLEY AND IRA LEVIN
}

\author{
NICULAE LIVIU GHERAN \\ Babeș-Bolyai University, Romania
}

\begin{abstract}
Within the present paper, I aim to discuss how Aldous Huxley and Ira Levin have employed the peripheral symbolic geography of their two works (Brave New World and This Perfect Day) to articulate their debate between different sets of social values. Unlike other authors of negative utopias such as George Orwell or Yevgeny Zamyatin, neither Huxley nor Levin idealized pre-modern values. In order to highlight how the two articulated their views with the help of symbolic geography, I will also make use of Michel Foucault's theoretical concepts of heterotopias, heterochrony as well as the ideas developed by the critics Michael Lowy and Robert Sayre in their seminal work Romanticism against the Tide of Modernity. My purpose is thus firstly to point out how and why Huxley and Levin divided the symbolic geography of their works in two parts as well as how they employed the Romantic critique of modernity. Secondly, I aim to show how despite using this analytical tool, they also employed symbolic geography with the purpose of turning the critique on its head, thus unveiling both its strong points as well as its shortcomings.
\end{abstract}

Keywords: dystopia, Modernism, Romanticism, Huxley, Levin, Malpais, heterotopia, Foucault.

The analysis of symbolic geography is fundamental when dealing with negative utopias because, to correctly highlight their criticism of ideas, concepts, or systems of social organization, the authors faced the problem of embodying those ideas into literary form. Dystopian (and utopian) fiction requires imagining communities that hold particular values and inhabit a specific

LiNGUACULTURE vol. 12, no. 2, 2021

Published: 31 December 2021

DOI: 10.4773/lincu-2021-2-0215

ISSN (print): 2067-9696 || ISSN (online): 2285-9403 || www.journal.linguaculture.ro 
geographic space. However, in the case of negative utopias, authors often do not imagine a single type of symbolic geography within their fictional spaces. In fact, they usually imagine at least two: one that stands at the center of the fictional universe and a peripheral one. Most criticism focuses on the central symbolic geography, yet the peripheral locations are also highly relevant from the perspective of our analysis. In my view, these locations are what Michel Foucault discusses in his essay "Des Espaces Autres" as being heterotopias. That is, spaces that are organized differently, often in symbolic opposition with the central geography. Kevin Hetherington (viii) discusses the strong relationship between heterotopias and issues of social ordering, of symbolic organization, of the transgression and resistance to the central symbolic order. These heterotopias are not only locations present in real life, as Foucault initially discussed them, but, in my opinion, they can be found within dystopian novels as well. In his essay, Foucault mentioned that space cannot be heterotopian by itself. A space is heterotopian in relation to another space. Concerning the savage reservation in Aldous Huxley's Brave New World, K.L Johnson notes in his essay on Brave New World titled "Ethics in the Late Anthropocene" that the World State in Huxley's novel views otherness with suspicion due to its stated motto of COMMUNITY, IDENTITY, STABILITY. However, in his view, the community's stability requires exposure to otherness from time to time to reassert its commitment to identity. For this reason, the world state itself cannot exist without its savages. The reservation is allowed to exist not because of the state's goodwill but because of necessity. A push-pull of unity and apartheid is necessary (Johnson 182). It works in the same manner in the case of Ira Levin's peripheral "Liberty Island." This fact is one of the main reasons we can label these spaces as heterotopias. They do not merely exist by themselves but are in constant relation to the central symbolic geography represented by the central symbolic topography.

Historically, within the genre of dystopian fiction, peripheral symbolic geography can be utopias in themselves, proposed by the authors as alternatives to the dystopian central order (like for example, the Uncharted Forest in Ayn Rand's Anthem or the space beyond the Green Wall in Yevgeny Zamyatin's We). They can also be spaces of refuge for the main characters from the dystopian city (like George Orwell's imagined Golden Country in 1984 or the countryside where he takes Julia). What all of these spaces have in common is their radically different symbolic organization vis a vis the dystopian city, as well as the fact that they seem to be associated with an anti-modern discourse rather than a modern one, one that I aim to show is tributary to the Romantic critique of modernity. 
Aldous Huxley and Ira Levin also imagined such peripheral spaces. However, what is different in the case of these two novels is that the authors adopted a more neutral tone concerning these peripheral locations. While other authors of negative utopias chose to idealize the peripheral location and, in the process, the anti-modern discourse associated with it, Huxley and Levin also want to point out the darker side of that discourse often ignored by other writers.

The central geographic space of the dystopian city is often a place that is associated with the characteristics that Max Weber assigned to modernity: the accounting spirit, the disenchantment of the universe, instrumental reason, and bureaucratic domination (Lowy and Sayre 19). To these we can add the mechanic state, collectivism and the rationalization of the environment. The peripheral spaces, however, can be associated with a discourse that is critical of modernity, focusing on the values of the pre-dystopian past, individualism, and in essence, a discourse that has a lot in common with the Romantic critique of modernity as expressed by Michael Lowy and Robert Sayre in Romanticism against the Tide of Modernity. The two authors argue that "one of the fundamental aspects of this Romantic critique was the conviction that in modern reality something precious has been lost, that certain essential values have been alienated at the level of both individuals and humanity at large." (Lowy and Sayre 22-23) For this reason, their quest is thus about searching for a lost past whose main feature is its difference from the present. In their view, "The Romantic vision selects a moment from the actual past in which the harmful characteristics of modernity did not exist and in which the human values that have been since stifled by modernity were still operative." (Lowy and Sayre 22-23)

Aldous Huxley makes multiple direct references to Romanticism through his parody of Thomas Gray's Elegy in a Country Churchyard at the beginning of Chapter V of Brave New World. Snow notes that the author replaces Gray's curfew bell with loudspeakers, his "drowsy tinklings" from the sheepfold with bells of trams, his "droning" flight of beetles with "an incessant buzzing of helicopters," and the church tower with the clubhouse tower (Snow 98). As Snow points out:

The essence of meaning in Huxley's novel lies in comparisons: past and future, emotion and sensation, pain and pleasure, nature and the unnatural, the rational and the irrational. As the reader recalls more and more of the "Elegy" he realizes that all which Gray celebrates is twisted or negated in the "Brave New World". Every value that Gray affirms has become a vice in Huxley's “future civilization”. The sources of pleasure noted by Gray include family affection, modest work and solitary reflection. They offer happiness to those who accept man's position in the natural order of things and accept his mutability. (Snow 98) 
On the other hand, it is clear that "the savage reservation" in the case of Huxley is a type of symbolic geography heavily steeped in the values of the pre-dystopian past and the author continues his references to Romanticism when depicting Bernard Marx as being highly interested in the idea of spending his free time in nature, more specifically in the Lake District, the famous location loved by the British Romantic poet William Wordsworth which, as so happens is within the reservation. Such desires are extremely uncommon and prohibited within the World State because the inhabitants of the state are psychologically conditioned to hate nature but love technological progress, any activity that does not require the usage of technology being discouraged with the help of the said conditioning. This is the reason why the scene in chapter 7 in which Bernard Marx asks Lenina to go out for a romantic walk with him in the Lake District is so important. She cannot understand the relevance of such an undertaking of just being alone with someone and talking all night. She prefers different forms of entertainment, more in tune with the values of the dystopian state that she has been conditioned to enjoy. Bernard has to explain to her that there is no scent, no television, and no hot water on the reservation so that she understands that the reservation is very different from the world of the city-state.

Furthermore, within the confines of the reservation, giving birth is still a natural process, with mothers keeping their children and taking care of them. Bernard Marx is fascinated by this aspect of life on the reservation and shares this with Lenina. Outside the reservation however, within the confines of the main symbolic geography, individuals are produced through in vitro fertilization and raised by the state in the dystopian city. The image of a woman breastfeeding is considered indecent. The social customs of the pre-dystopian world order, such as the traditional family, marriages, the absence of conditioning, the presence of religions, and languages long extinct, are maintained within the reservation. These, however are considered primitive in the rest of the fictional world. In fact, within the state, the image of God has been replaced with that of Henry Ford (the one who developed the mass production of automobiles). This particular aspect is also very significant because, on the one hand, "the Fordist" system that dominates the central topography does not limit itself to the mass production of material goods, but is extended to the mass production of individuals through genetic engineering. Originality and any deviation from the norm are discouraged, and the political system itself makes such deviation almost impossible. Those that cannot perfectly integrate within the system (such as Bernard Marx or John the Savage) are in a sense being considered "production errors." 
When discussing the Romantic critique of modernity, Michael Lowy and Robert Sayre (22-23) point out that the Romantics also looked back towards an era in which the modern socio-economic system did not exist. Schelling complained in Das alteste System des deutschen Idealismus that every state treats free human beings like a mechanical system of gears [mechanisches Raderwerk.] (C.f. Lowy and Sayre 39) Similarly, Novalis complained that "in no state has the administration so perfectly resembled a factory as in Prussia since the death of Friedrich Wilhelm I.” (313) Thus, one of the nightmares of the Romantics is brought to new heights by novelists such as Huxley. This happens because in his novel, not only are we dealing with a perfectly regimented industrial society in which individuals lifelessly, mechanically, and monotonously produce things but, more than that, we are dealing with a society in which individuals themselves are mass-produced through the same type of industrial process. There is no room for originality, individualism, much less romantic genius. On the issue of individualism, in particular, Lillian Furst argues in her work Romanticism in Perspective that the Romantics were the first to turn individualism into a worldview in European culture. (Furst 26) She argues that Romanticism represents the first significant point of convergence of individualist values within a literary, philosophical and social current that elevates the individual consciousness of every person to the stature of final arbiter of the universe observed from a human perspective (Furst 26). Individualism, however is made to be almost impossible in Huxley's Brave New World society of casts, where every member is a clone of others. As Malinda Snow shows, the amalgamation of the individual into the social structure of the novel is accomplished by denying him specific recognition (Snow 98). Indeed, the only two characters that can be considered individuals/individualists are Bernard Marx and John the Savage. Bernard cannot quite fit in the dystopian world while John similarly cannot fit in the reservation.

If the Romantics' view of the industrial city was that of a dark urban environment in which the individual is condemned to dehumanization through the severing of the connection between man and nature, in Huxley's world, dehumanization starts from the very moment of birth. It is also being followed by a draconic psychological program made possible through the various modern procedures available in the dystopian world. The aging process is also not tampered with in the savage reservation. This fact contrasts with the central dystopian topography where man has managed to eliminate the unaesthetic effects of old age due to the advances of science. Within the city-state, life span is guaranteed to be kept at the standards of youth until 60, when it ends automatically. This theme of controlling the age span of individuals is recurrent in negative utopias. Whether we have in mind novels such as Logan's 
Run, Brave New World, Lord of the World, or This Perfect Day, the aging processes are manipulated by the state to bring all citizens up to a certain age, after which they are eliminated or self-eliminate themselves through assisted euthanasia. In contrast, within the confines of the reservation, individuals get old and die naturally at different ages.

What is different concerning Huxley's peripheral geographic space is that, although the author is critical of the fact that any superstition, tradition, or the social connection between individuals has been eliminated from the modern world in the name of rationalism, he does not condone the bloody rituals practiced by the Malpais natives. The author presents us with a scene in which the natives select a young man and then whip him to produce rain. Nor does he condone physical violence caused by jealousy. (John's mother, Linda, is whipped by other women after sexual intercourse with multiple men from the same village.) As David Sisk points out, the name of the reservation comes from French: mal pays, meaning evil place or bad country (Sisk 122). The name is the exact opposite of the Greek origin of Utopia, "eu-topos" (good place). Raychel Reiff shows how the reservation is the mirror image of the World State, making a few parallels mentioning the role history plays for both societies, their moral coerciveness, and violence (Reiff 78). In fact, Huxley himself argued in the foreword ${ }^{1}$ to the 1946 reprint of Brave New World that the symbolic geography of the World State offers a life of insanity while the Indian village offers a life of lunacy. Thus, we can observe the fact that the author has an ambivalent outlook which oscillates and seeks to find a balance between the two dimensions. In a sense, eliminating all the traditional attributes of humanity is wrong, but it is obvious that the author believes not all such traditions are worth keeping. This balance is best reflected in the character of John the Savage. John's father belongs to the urbanized modern environment of the world state, but his mother raised him on the territory of the native reservation. Thus, John has a genetic makeup in common with those belonging to the higher castes of society while, at the same time, the environment in which he grew up was highly different. Through this feature, we can observe how, what the author wants to highlight is not necessarily the superiority of one type of symbolic geography over another (as we have in the case of Orwell or Zamyatin) but the fact that both worlds, the one constructed as a bastion of modernity, genetic engineering and rationalism, as well as that of the natives, carry symbolic values important to human civilization.

\footnotetext{
${ }^{1}$ Huxley wrote this "Foreword" in 1946 for the reissue of Brave New World in 1950 in the Collected Edition of his works. It contains the author's thoughts about the novel fourteen years after it was published. (Cf. Meckier 1979)
} 
The practical purpose for which Huxley recourses to the Romantic critique of modernity is thus not to idealize pre-modernity (as other negative utopian authors did) but to more accurately highlight his critical attitude towards modernity and the pre-dystopian past. The Romantic critique is a tool in the writer's arsenal. We cannot speak about a total rejection of modernity but of a partial criticism. We can understand this philosophical position better by examining what critics such as Michael Lowy and Robert Sayre mentioned in their work as being both the strong and the weak aspects of the Romantic critique, aspects of which Huxley was well aware. The weak aspect of this type of criticism is that, on the one hand, anything new can quickly end up being looked at with skepticism or hate. Such concepts include the idea of progress, rationality, and its potentially positive aspects. In Lowy and Sayre's opinion, this leads to a certain type of "autism" that is certainly not useful within any kind of social or ideological dialogue (Lowy and Sayre 249). However, on the other hand, the criticism of modernity through a Romantic lens has the merit of highlighting the noticeable negative features of modernity, thereby managing to create a lucid current of opposition that can efficiently combat a different type of modern "autism" which is the blindness to the adverse effects that modernity brought forward in our socio-cultural context. Social reification, alienation, the quantifying of human existence, the loss of cultural values, the degradation of the natural world, the uncontrollable dynamic of machines and technology, all of these elements were correctly associated with the modern ethos in the 19th century for the first time. In short, the Romantics highlighted a facies hippocratica of modern civilization (Lowy and Sayre 250). Thus, despite any other features it may have had, Romanticism becomes a critical instrument for the following centuries, one that will not lose its relevance over time for the simple reason that the negative aspects of modernity have themselves not disappeared as history progressed. As long as modernity and the modern ethos influence society, they will carry with them the shadow of the romantic critique, and this will happen independently of the will of either critics or proponents of modernity.

Returning to our initial topic, we can observe that Aldous Huxley chose to create the peripheral topography of the Malpais reservation as a true bastion of the pre-dystopian past to make use of the ideological fortitude characteristic of the Romantic critique to highlight the mentioned facies hippocratica of modernity. However, far from simply idealizing the entirety of Malpais culture, he also used symbolic geography to highlight its negative aspects and thus turn the critique on its head.

Huxley could have created a third space, a utopia that contains the positive aspects of both modernity and pre-dystopian past. In such space all, or the great majority of the negative aspects of both could have been eliminated. 
His good friend D.H Lawrence actually suggested this course by criticizing the fact that his character, John the Savage, has only these two alternatives to choose from as being "the most serious defect in the story." (qtd. in Miller 149) This fact, however, does not change the ways through which the author constructed the peripheral symbolic geography represented by the savage reservation.

Another novel written in a similar vein would be Ira Levin's This Perfect Day. In Levin's fictional universe, similar to Huxley's, we are not dealing with a world in which the standard of living is low (as we have in the case of George Orwell's 1984), but one in which people live in a perfectly organized and rationalized material prosperity. In Levin's book the world is organized by a supercomputer named Unicomp. This computer decides all the activities in the day-to-day lives of the citizens. Human nature is a disease that needs to be treated via medical procedures and drugs within the confines of the dystopian state. Similarly to Huxley's Brave New World, symbolic space seems to be divided in two parts, a central topography that contains the symbolic attributes of totalitarian modernity and a pre-dystopian peripheral one in which the strict rules, treatments, and the controlling characteristics of the central topography are missing. The novel is centered on the main character (Chip), who revolts against the dystopian establishment. Chip firstly joins a group that manages to avoid the medical treatment through which the behavior of the population was controlled and then by leaving in search of a possible location where the dystopian order was not yet established. Lilac asks Chip the following question: “'Do you think it's possible that the incurables are still alive?' He looked at her. 'That their descendants have survived somehow,' she said, 'and have a —a society somewhere? On an island or in some area that the Family isn't using?'” (Levin 128)

In fact, within the dystopian central topography, many myths circulate about the place where people live "off the grid". Of course, the individuals are referred to as barbarians, incapable of appreciating the advantages of the modern world. They are named "the incurables" because they choose not to receive the medical treatments applied to the citizens living within the dystopian city-state. The main character wants to find and move to this heterotopia, even if it means living on plants and wild animals. (Levin 130) Other dystopian science fiction novels have presented us with similar scenarios. For example, the main character from Ayn Rand's dystopia, Anthem, also chooses the path of exile and procuring his own food outside the confines of the totalitarian (yet comfortable) city-state. For Rand, this is an individualist manifesto because the idea of self-sufficiency is a sign of individual empowerment in the face of the collectivistic nature of the dystopian state. What we have discussed concerning Romanticism and individualism in the case of Huxley's novel also holds for Levin. One of the main aspects of Levin's fictional world is perfect ethnic uniformity. There is a single race called The Family and there are only four names available for men and four for women, 
individuals being distinguished by a nine-character alphanumeric code. Genders are also indistinguishable from each other as men stopped growing facial hair and women do not develop breasts. All individuals have the same behavior, they eat totalcakes, drink Coke and wear the same clothes. Only the main character has a name that is different from others (Chip), a name given by his grandfather, who was also something of a rebel. He is a "chip of the old block," as his grandfather calls him. As Maria Manuel Lisboa points out, "utopia requires absolute, highly regulated conformism. By the same token, under utopia, the price of nonconformism (the freedom to be different) is unhappiness and ultimately punishment." (Lisboa 151) In contrast, the traits of the Romantic Hero have traditionally been the rejection of authority, introversion and isolation, a feeling of wanderlust and being haunted by the past. Chip rejects the authority of Uni, is introverted as the novel portrays him as not enjoying the time spent together with other members of The Family (very similar to Huxley's Bernard Marx in this respect), and is curious about life in the predystopian past, desiring its return. His act of destroying Unicomp, disobeying "God" (in our case the rulers of the dystopia) and returning freedom back to mankind is akin to the myth of the titan Prometheus, as Romantics such as P.B Shelley understood it. Similarly, the classification of the populations living outside the control of the state being labeled as: incurables, savages, barbarians, etc. is a common trope within negative utopias (Levin 144). Nature (which the author idealizes) is perceived as a disease that needs to be treated within "The Family" (Levin's equivalent of the World State), rather than something that needs to be embraced. John Hickman argues that Levin expressed anxieties about a society that suppresses the competition and conflict within a society necessary to give life meaning (Hickman 141). In his search, Chip visits a museum of the pre-dystopian world in the archives of which he finds multiple possible geographic locations situated outside the control exercised by Unicomp. Islands such as Cuba, Majorca, the Falklands, or Madagascar appear as topographies where alternative communities seem to be possible.

However, the difference between the idealizing expectations that the main character has from alternative spatiality and certain pragmatic realities resulting from the absence of the control exercised by Unicomp is made visible by the author. Chip finds out that indeed individuals have greater autonomy than they do in the geographic topography organized by Unicomp. However, this liberty comes at a price. For example, in the alternative spatiality where Chip ends up, the isle of Majorca (now renamed Liberty Island), the material problems have not been solved; hunger, crime, and many chronic diseases Unicomp had eliminated continue to spread in this area. People also work much more than the inhabitants of the city. As in the case of Huxley's Brave New World, religion is still present in this society. On the other hand, although 
individuals do not have an age limit set at a global level and therefore can theoretically live past the age of 60 , many do not get to 30 due to diseases, alcoholism, and internal wars.

The central topography ruled by Unicomp has been pacified and wars have been eliminated. However, peripheral geography is highly volatile due to the presence of greater autonomy of individuals and, in part, because they have not received genetic treatments to limit their natural aggression. Despite all this, they choose not to return to the city-state. Chip does manage to reach a predystopian universe in which the individual is relatively free. However, he also notices the less than ideal elements that stem from a lack of centralized control. He is greeted by one of the inhabitants, saying, "I'm sorry to disappoint you, but you haven't come to any paradise.” (Levin 222) This brilliant statement flies in the face of countless other authors of dystopian fiction who presented peripheral geography as utopias. The characters inhabiting Levin's marginal topographic location are neither anarchistic rebels fighting for freedom like in the case of Zamyatin, nor are they philosophical individualists like in the case of Ayn Rand, nor is their topography a space where the main character can experience love, erotic and emotional connection like in the case of Orwell. They are described as "ignorant," "inbred," "mean," "self-satisfied," are often criminals, violent, and "hateful of newcomers." (Levin 222) In one of the final scenes of the novel, Chip meets one of the World Controllers of the dystopian state and asks him why The Family can't make decisions for himself. Wei replies that simply because, left uncontrolled and unattended they are incapable of doing so, that people left in their natural state (as Chip met on the island) are mean, foolish, aggressive and motivated only by selfishness and fear (Levin 222).

Like Huxley, who, as we have seen, highlights the superstitious, irrational traits of the natives living in the reservation (which he does not find in any way desirable), Ira Levin seems to stress the fact that, although there are desirable aspects of the pre-dystopian world, there is also another way of looking at things. Not all the characteristics of the pre-dystopian world are enviable in the same manner in which not all the characteristics of the modern world are undesirable. Chip is initially portrayed as a rebel on the quest (Lowy and Sayre would say, a Romantic quest) to find the lost past whose main feature is its difference from the present. And indeed he does, but reality is less than ideal, to say the least. Nevertheless, in Ira Levin's book, the final choice of the main character who is faced with the different contrasts between the two worlds is more romantic than reasonable and pragmatic. Chip chooses to return to the dystopian city and destroy Unicomp, and he succeeds in doing so. Thus we see how the main idea of Levin's text is that, despite the risks involved in a 
decentralized world that lacks the extreme rationalization of individuals, of the environment, of genetic treatments that modify human nature or other modern methods of artificial pacifying, a world in which the individuals have autonomy and do not naturally take rational decisions concerning their own life or the society they live in, a world of instinct and impulse, of dynamic flux in opposition with the static and sterile environment is, in the end, to be preferred. This is indeed an argument of romantic origin, even radically so. This is because, in contrast with Huxley, who chooses to oscillate between the positive values of the past and the present as well as their negative correspondents, we can observe in the case of Levin the existence of a clear option: he inclines towards the return to a pre-dystopian paradigm of the past, and his character manages in the end to destroy the computer that organizes the private lives of the citizens living in the central dystopian symbolic space despite the trouble that may arise (Levin 331). The peripheral alternative world that Chip encounters is not utopian anarchy as we have in the case of Zamyatin, but the values that stand at the basis of this world are idealized and preferred to the values characteristic of the modern world.

In conclusion, we have seen how both authors created heterotopias within their fictional texts in order to showcase their critique of the modern dystopian city. The organization of space and the values they represent stem from the Romantic critique of modernity and can be associated with an anti-modern worldview. That being said, the authors do not merely idealize this romantic critique. They prefer to also highlight that the critique itself has its own weak points. The past might have been a time when specific essential values existed which have been alienated by modernity and the present - but scientific progress and the elimination of particularly violent traditions from society have merit.

\section{Works Cited}

Foucault, Michel. "Of Other Spaces." in Architecture, Mouvemont, Continuite. Translated by Jay Miskowiec. October, 1984.

Hickman, John. "When Science Fiction Writers Used Fictional Drugs: Rise and Fall of the Twentieth-Century Drug Dystopia.” Utopian Studies, vol. 20, no. 1, 2009, pp. 141-170, Penn State University Press. http://www.jstor.org/stable/20719933.

Huxley, Aldous. Brave New World. Perennial Classics, 1998.

Huxley, Aldous, "Preface." Brave New World and Brave New World Revisited. Harper Perennial, 2005.

Johnson, Keith "Ethics in the Late Anthropocene." Brave New World: Context and Legacies, edited by Jonathan Greenberg and Nathan Wadell, Palgrave Macmillan, 2016, pp.169-189. 
Hetherington, Kevin. The Badlands of Modernity, Heterotopia and Social Ordering. Routledge, 2003.

Levin, Ira. This Perfect Day. Penguin Books, 1970.

Furst, Lillian. Romanticism in Perspective. Macmillan, 1969.

Lisboa, Maria Manuel. The End of the World: Apocalypse and its Aftermath in Western Culture. Open Book Publishers, 2011.

Lowy, Michael, Robert Sayre. Romanticism against the Tide of Modernity. Duke University Press, 2001.

Meckier, Jerome. "A Neglected Huxley 'Preface': His Earliest Synopsis of Brave New World.” Twentieth Century Literature, vol. 25, no. 1, [Duke University Press, Hofstra University], 1979, pp. 1-20, https://doi.org/10.2307/441397.

Miller, Toy Katherine. "Deconstruction the Savage Reservation.” Huxley's Brave New World: Essays, edited by David Garett Izzo and Kim Kirkpatrick, McFarland and Company, London, 2008, pp. 145-60.

Novalis. Werke. Hadecke Verlag, 1924.

Reiff, Raychel Haugrud. Writers and their Work: Aldous Huxley's Brave New World. Marshall Cavendish, 2010.

Schelling, F. "Das alteste Sustem des deutschen Idealismus." Romanticism against the Tide of Modernity, edited by Michael Lowy and Robert Sayre. Duke University Press, 2001.

Sisk, David W. "Using Language in a World that Debases Language." Readings on "Brave New World, edited by Katie de Koster. Greenhaven Press, 1999, pp. 122-129.

Snow, Malinda, “Malinda Snow on Huxley’s Use of Thomas Gray’s ‘Elegy in a Country Church Yard,"” Bloom's Guides: Aldous Huxley's Brave New World, edited by Harold Bloom. Chelsea House Publishers, 2004, pp. 97-100.

\section{BIONOTE}

Niculae Liviu Gheran, Ph.D., currently teaches at Babeș-Bolyai University at the Department of Languages for Specialized Purposes. His $\mathrm{PhD}$ is on Negative Utopias, more specifically on $19^{\text {th }}$ Century influences in $20^{\text {th }}$ Century Negative Utopias. He has published several papers and edited post conference volumes on the topic in the UK, the Czech Republic, and Romania.

Email: gheran.niculae@yahoo.co.uk 